\title{
Lyfjaávísanir í réttum höndum?
}

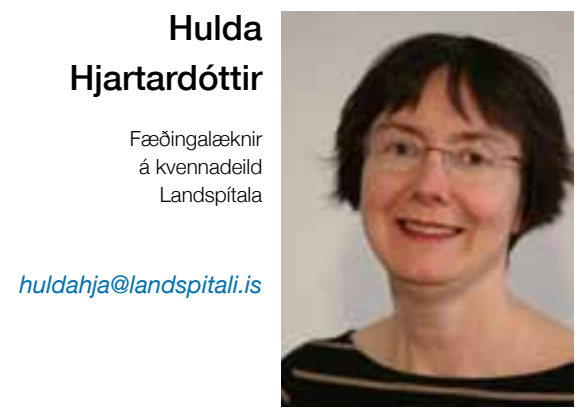

Nýlega lagði velferðarráðherra fram frumvarp um breytingar á lyfjalögum og lögum um lýðheilsu (ávísanaheimild) par sem á að veita hjúkrunarfræðingum og ljósmæðrum heimild til að ávísa hormónatengdum getnaðarvörnum að undangenginni sérstakri pjálfun eða kennslu. Pessi frumvarpsdrög hafa valdið pó nokkurri umræðu meðal lækna og hjúkrunarfræðinga/ljósmæðra eins og fram hefur komið í fjölmiðlum, enda er parna um grundvallarbreytingu og skörun á starfssviði pessara stétta að ræða pó í litlum mæli sé. Málið á sér nokkurn aðdraganda og er hægt að rekja pað aftur um nær 5 ár. Árið 2007 óskaði landlæknir eftir áliti Félags íslenskra fæðinga- og kvensjúkdómalækna (FÍFK) varðandi tillögur páverandi ráðherra heilbrigðismála um takmarkað leyfi hjúkrunarfræðinga og ljósmæðra til að skrifa upp á hormónagetnaðarvarnir. FÍFK skipaði starfshóp til að fjalla um málið og komst hópurinn að peirri niðurstöðu að ekki væri pörf á slíkum breytingum. Í fyrsta lagi hefði mikill árangur náðst í fækkun fóstureyðinga almennt, og pá sérstaklega í yngstu aldurshópunum. Fæðingatíðni kvenna yngri en 20 ára væri aðeins um 1,3\% og væri pví ekki stórt heilsufarvandamál. Í öðru lagi væri óparfi að bæta við starfsfólki sem gæti ávísað hormónagetnaðarvörnum pví aðgengi fólks að getnaðarvörnum eins og getnaðarvarnapillunni væri gott, stutt bið væri eftir að hitta lækna í heilsugæslu og á stofum og menntun lækna gerði pá til pess fallna að skrifa lyfseðla en ekki menntun hjúkrunarfræðinga. Hægt væri að bæta aðgengi ungs fólks að getnaðarvörnum á annan hátt, til dæmis með verðlækkun. Tekið var fram í bréfinu að ef niðurstaða pessa máls innan stjórnkerfisins yrði önnur en álit FÍFK, kallaði pað á frekari umræðu meðal fagfólks: heimilislækna, lyfjafræðinga og háskólakennara. Prátt fyrir petta álit sendi páverandi landlæknir erindi til ráðherra par sem mælt var með pví að lögum yrði breytt samkvæmt ofangreindu. Ekki heyrðist meira af pessu máli par til allt í einu að boðað var til fundar í velferðarráðuneytinu í nóvember síðastliðnum. Var undirrituð pó aðeins boðuð á fundinn vegna pess að athugull framkvæmdastjóri Læknafélagsins tók eftir pví í fundarboði að fulltrúi FÍFK hafði ekki verið boðaður og hafði samband við ráðuneytið. Fjöldi manns var boðaður á fundinn, fulltrúar hinna ýmsu fagfélaga, ljósmæðra, hjúkrunarfræðinga, lyfjafræðinga, heilsugæslunnar og háskóladeilda. Á fundinum voru drög að frumvarpinu kynnt og óskað eftir athugasemdum. Flestir peirra sem á fundinum voru lýstu yfir ánægju sinni með frumvarpsdrögin. Rök á móti komu flest frá fulltrúum peirra fagfélaga lækna sem á fundinum voru og frá heilsugæslulæknum. Mikill meirihluti fulltrúa á fundinum var ekki læknismenntaður. Рað kom fram á fundinum að petta frumvarp yrði lagt fram og of seint væri að koma með skriflegar athugasemdir.

Frumvarpið hefur verið í umfjöllun pingflokka en ekki náðist að leggja pað fram formlega á pessu pingi. Af hálfu félaga î FÍFK og FÍH var strax brugðist við til að reyna að leiðrétta rangfærslur sem fram komu í rökstuðningi með frumvarpinu. Er par vísað til pess að haft hafi verið samráð við heilbrigðisvísindasvið Háskóla Íslands, Embætti landlæknis og Lyfjastofnun. Ekki er minnst á pá sem höfðu aðra skoðun á málinu og komu henni á framfæri við undirbúning málsins. Í rökstuðningi með frumvarpinu er einnig vísað í skýrslu Barnaréttarnefndar Sameinuðu pjóðanna sem birtist síðla árs 2011. Í skýrslu nefndarinnar koma fram áhyggjur af pungunum stúlkna, 18 ára og yngri, og eru pær taldar geta stafað af pekkingarskorti og lélegu aðgengi peirra að getnaðarvörnum og ráðgjöf um pær. Leggur nefndin til að aðgengi pessa hóps að getnaðarvörnum verði bætt.

Í skýrslu nefndarinnar er byggt á tölum sem teknar eru úr samhengi við próun síðustu ára og sem eru að minnsta kosti 6 ára gamlar. Bent skal á að mikill árangur hefur náðst í að fækka pungunum og barnsfæðingum meðal stúlkna á pessum aldri. Fjöldi fæðinga hjá stúlkum yngri en 17 ára var um $1 \%$ allra fæðinga fyrir 30 árum en er nú aðeins $0,1 \%$. Sömu sögu má segja um fæðingar í aldurshópnum yngri en 18 ára sem voru rúmlega $3 \%$ fyrir 30 árum en eru nú um 0,5\%. Fæðingar í pessum aldurshópi hafa alltaf verið fleiri en á hinum Norðurlöndunum og er sennileg skýring á pví að nokkru leyti menningarmunur. Hvað snertir fóstureyðingar er Ísland í næstneðsta sæti meðal Norðurlandanna. Fjöldi fóstureyðinga í aldurshópnum 15-19 ára var 21/1000 fæðingar árið 1999 en var 12/1000 árið 2009. Tíðni fóstureyðinga er hæst 1 Svípjóð og Noregi par sem ljósmæður og hjúkrunarfræðingar hafa fengið takmarkað ávísanaleyfi. Í frumvarpinu er engin útfærsla á nauðsynlegri viðbótarmenntun pessara starfsstétta né tilkostnaður við hana. Lítill munur er á kostnaði við vinnu lækna og hjúkrunarfræðinga í heilsugæslunni. Pegar grannt er skoðað liggja pví hvorki sterk kostnaðarleg né fagleg rök að baki pessum breytingartillögum.

Tillögur um breytingar á lögum um lyfjaávísanir ætti að gera í góðu samráði við lækna sem er eina starfsstéttin sem hefur nauðsynlega menntun til pess starfa. Ég legg til að fyrirhugað frumvarp verði dregið til baka og haldið verði áfram vinnu við að fræða ungt fólk um kynlíf og getnaðarvarnir í góðri samvinnu lækna, hjúkrunarfræðinga og ljósmæðra.

Should other health professionals than doctors be allowed to prescribe hormonal contraception?

Hulda Hjartardóttir: Consultant Obstetrician 